\title{
Abdominal Aortic Aneurysm of Unknown Origin and Renovascular Hypertension in a 25 Year Old Male
}

\author{
Yoshihiko Hirata, M.D., Keijiro Saku, M.D., \\ Manabu Sasaguri, M.D., Yoshitaka Higashi, M.D.,* \\ Masaharu Ikeda, M.D., and Kikuo Arakawa, M.D.
}

\begin{abstract}
Summary
A 25 year old male had an abdominal aortic aneurysm involving bilateral renal arteries. Aortography revealed no irregularity in the aortic wall but a slight kinking at the tenth thoracic level followed by a fusiform aneurysm. Computed tomography (CT) showed an enlarged aortic lumen with an intraluminal thrombus. Plasma renin activity (PRA) was markedly increased $(11 \mathrm{ng} / \mathrm{ml} / \mathrm{h})$, and the administration of captopril caused a further increase in PRA with a significant reduction in blood pressure, indicating the presence of renovascular hypertension. Abdominal aneurysm in a young adult is very rare. The etiology of the aneurysm appears to be idiopathic.
\end{abstract}

Additional Indexing Words:

Abdominal aortic aneurysm Renovascular hypertension Renin

Captopril test

\section{Case Report}

T.N. is a 25 year old Japanese male who was admitted on July, 1986 for cvaluation of severe hypertension $(200 / 140 \mathrm{mmHg})$. He was well until 2 months prior to admission when he had headache, back and flank pain. There was a family history of hypertension; his father died from apoplexy at the age of 52 years, but there was no family history of malignant tumor, tuberculosis or other pulmonary disease. Laboratory studies (Table I) revealed an elevated WBC of 13,000 (stab $8.9 \%$, segm $47.5 \%$, lympho $32.7 \%$ ) and a positive CRP $(+)$ with normal urinalysis and blood chemistry. Erythrocyte sedimentation rate was $3 \mathrm{~mm} / \mathrm{h}$ and gamma-globulin was $12 \%$. Serological examination for rheumatoid factor, LE test, antinuclear antibody, hepatitis B antigen and syphilis (STS) were all negative. Plasma renin ac-

From the Department of Internal Medicine and Department of Radiology, Fukuoka University School of Medicine, Fukuoka, Japan.

Address for reprints: Keijiro Saku, M.D., Department of Internal Medicine, Fukuoka University School of Medicine, 45-1, 7-chome, Nanakuma, Jonan-ku, Fukuoka 814-01, Japan.

Received for publication August 31, 1987.

Accepted July 6, 1988. 
tivity (PRA) was increased to as high as 11 (controls: $0.3-2.9$ ) $\mathrm{ng} / \mathrm{ml} / \mathrm{h}$ and aldosterone was also increased to 170 (controls: 10.9-62.7) pg/ml. CT examination showed an enlarged aortic lumen with a rim of nonenhancing intraluminal thrombus and a calcified aortic wall (Fig. 1). Aortography was carried out and showed a slight kinking of the aorta at the tenth thoracic level, followed by aneurysmal dilatation of the abdominal aorta; no definite evidence of renal artery stenosis was observed (Fig. 2). Renogram revealed

Table I. Laboratory Findings

\begin{tabular}{|c|c|c|c|c|c|c|}
\hline ESR & $3 / 8 \mathrm{~mm}$ & \multicolumn{2}{|l|}{ Biochemistry } & \multicolumn{3}{|c|}{ Electrolytes } \\
\hline WBC & $13,000 / \mathrm{mm}^{3}$ & $\mathrm{TP}$ & $6.7 \mathrm{~g} / \mathrm{dl}$ & $\mathrm{Na}$ & \multicolumn{2}{|c|}{$139 \mathrm{mEq} / \mathrm{l}$} \\
\hline stab & $8.9 \%$ & T-Bil & $1.1 \mathrm{mg} / \mathrm{dl}$ & $\mathrm{K}$ & \multicolumn{2}{|c|}{$3.7 \mathrm{mEq} / \mathrm{l}$} \\
\hline segm & $47.5 \%$ & GOT & $18 \mathrm{IU} / \mathrm{l}$ & $\mathrm{Cl}$ & \multicolumn{2}{|c|}{$100 \mathrm{mEq} / 1$} \\
\hline eosino & $1.0 \%$ & GPT & $36 \mathrm{IU} / \mathrm{l}$ & $\mathrm{Ca}$ & \multicolumn{2}{|c|}{$4.7 \mathrm{mEq} / \mathrm{l}$} \\
\hline baso & $0 \%$ & $\mathrm{LDH}$ & $326 \mathrm{IU} / 1$ & \multicolumn{3}{|l|}{ Serology } \\
\hline lympho & $32.7 \%$ & $\mathrm{Al}-\mathrm{P}$ & 192 G-R U & \multicolumn{3}{|c|}{ RA test $(-)$} \\
\hline mono & $9.9 \%$ & Ch-Ease & $275 \mathrm{IU} / 1$ & \multicolumn{3}{|c|}{ HBs Ag (-) } \\
\hline $\mathrm{RBC}$ & $523 \times 10^{4} / \mathrm{mm}^{3}$ & CPK & $65 \mathrm{IU} / \mathrm{l}$ & \multicolumn{3}{|c|}{ TPHA (-) } \\
\hline $\mathrm{Hb}$ & $17.5 \mathrm{~g} / \mathrm{dl}$ & T-Chol & $147 \mathrm{mg} / \mathrm{dl}$ & \multicolumn{3}{|c|}{ LE test $(-)$} \\
\hline $\mathrm{Ht}$ & $49.0 \%$ & TG & $93 \mathrm{mg} / \mathrm{dl}$ & IgG & \multicolumn{2}{|c|}{$1,380 \mathrm{mg} / \mathrm{dl}$} \\
\hline Urinalysis & & HDL-C & $31 \mathrm{mg} / \mathrm{dl}$ & $\operatorname{Ig} \mathrm{A}$ & \multicolumn{2}{|c|}{$286 \mathrm{mg} / \mathrm{dl}$} \\
\hline protein & $(-)$ & BUN & $14 \mathrm{mg} / \mathrm{dl}$ & $\operatorname{IgM}$ & \multicolumn{2}{|c|}{$140 \mathrm{mg} / \mathrm{dl}$} \\
\hline sugar & $(-)$ & $\mathrm{Cr}$ & $0.9 \mathrm{mg} / \mathrm{dl}$ & \multicolumn{3}{|c|}{ Captopril test } \\
\hline o. b. & $(-)$ & CRP & $0.7 \mathrm{mg} / \mathrm{dl}(+)$ & & PRA & PAC \\
\hline \multirow{2}{*}{\multicolumn{2}{|c|}{ sediment n. p. }} & PRA & $11 \mathrm{ng} / \mathrm{ml} / \mathrm{h}$ & pre & 8.8 & 170 \\
\hline & & Aldosterone & $170 \mathrm{pg} / \mathrm{ml}$ & $60 \mathrm{~min}$ & 59 & 160 \\
\hline
\end{tabular}

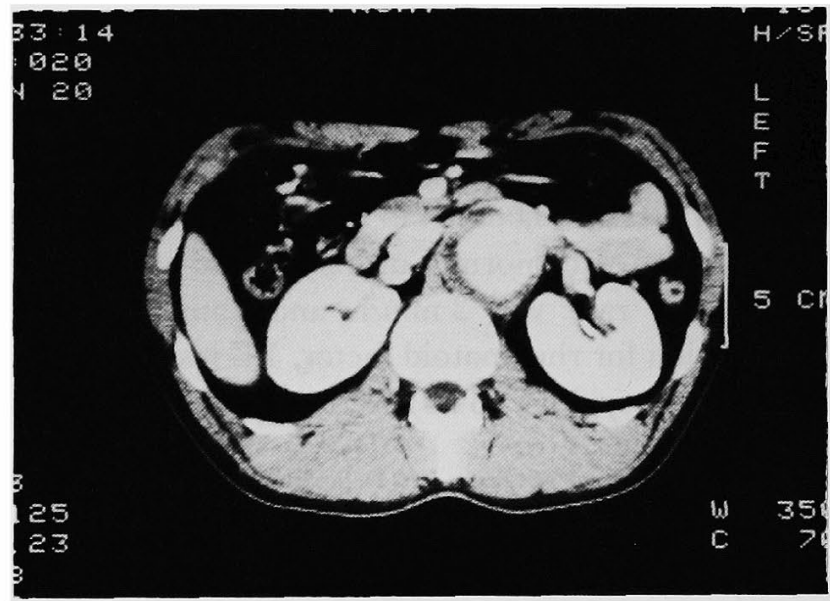

Fig. 1. Postcontrast scan of aortic aneurysm. The lumen is enlarged and thrombotic with a partially calcified wall. 


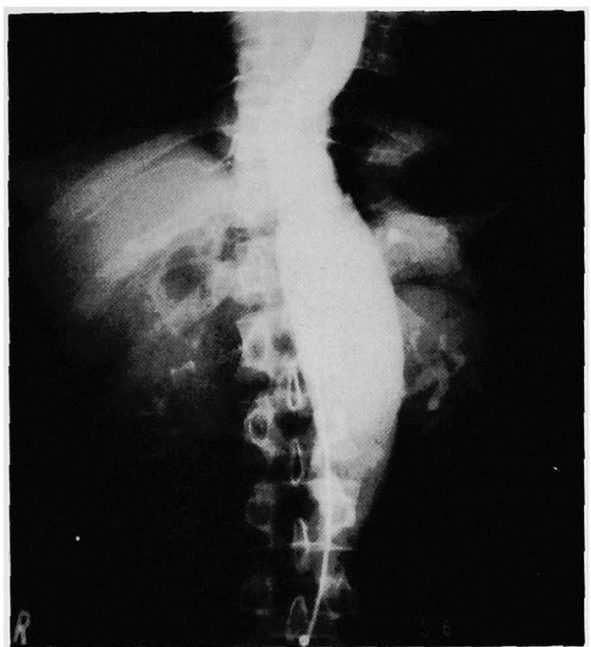

Fig. 2. AP aortogram. Aorta kinks slightly at the level of Th-10, distal to which a fusiform aneurysm with a smooth aortic wall is present.

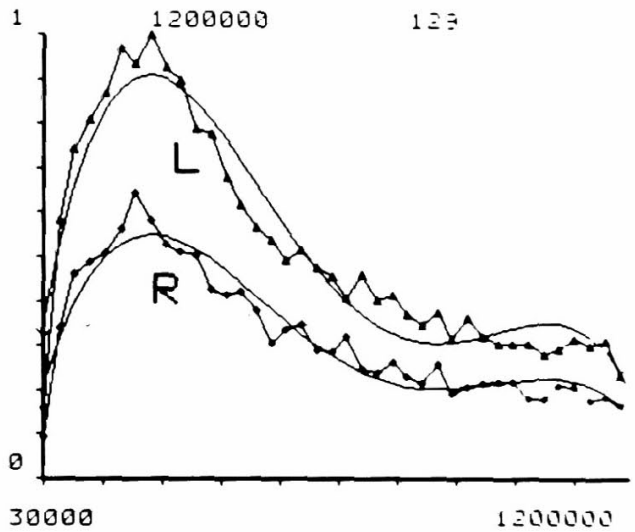

Fig. 3, Renogram using ${ }^{131}$ I-hippuran. A significant reduction of the secretory segment (renal blood flow) was observed in the right kidney (R).

a significantly reduced secretory segment (renal blood flow) of the right kidncy (Fig. 3), whilc renoscintigram showed significant rcductions in size and ${ }^{99 \mathrm{~m} T \mathrm{~T}}$ uptake of the same kidney (Fig. 4). Plasma renin activities (PRA) from the right and left renal veins and inferior vena cava were 14.0, 9.3 and $9.9 \mathrm{ng} / \mathrm{ml} / \mathrm{h}$, respectively. A right/left renal vein renin ratio was 1.51 and the indices of renal vein renin to systemic renin were 0.41 (right) and 0 (left), respectively. The captopril test (25 $\mathrm{mg}$ captopril) showed a marked increase in PRA from $8.8 \mathrm{ng} / \mathrm{ml} / \mathrm{h}$ at baseline to $59 \mathrm{ng} / \mathrm{ml} / \mathrm{h}$ at $60 \mathrm{~min}$ after administration. It also resulted in a significant reduction in blood pressure from 


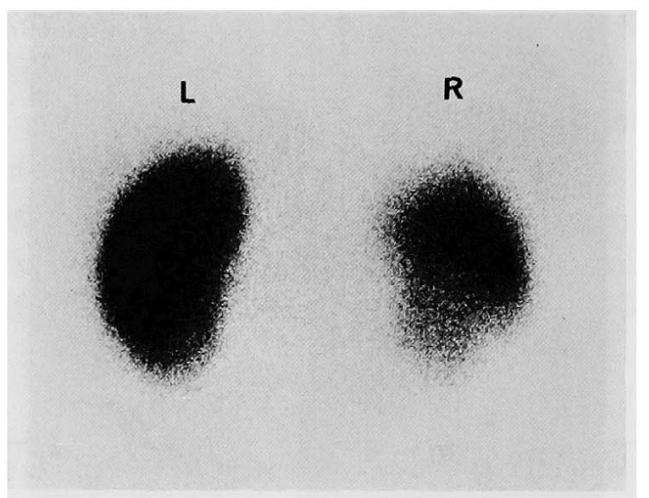

Fig. 4. Renoscintigram using ${ }^{99 m}$ Tc-DMSA. Significant reductions in size and uptake of isotope were observed in the right kidney ( $R)$.

$162 / 126 \mathrm{mmHg}$ to $148 / 110 \mathrm{mmHg}$, a reduction in mean blood pressure of $15.4 \mathrm{mmHg}$. In addition, infusion of the angiotensin antagonist, (Sar $\left.{ }^{1}, \mathrm{Ile}^{8}\right)$ angiotensin II at a rate of $400 \mathrm{ng} / \mathrm{min} / \mathrm{kg}$, significantly lowered blood pressure from $163 / 117 \mathrm{mmHg}$ to $143 / 102 \mathrm{mmHg}$, with a mean blood pressure reduction of $16.7 \mathrm{mmHg}$.

\section{Discussion}

Abdominal aortic aneurysms are usually found in the infrarenal aorta and their incidence increases with age. ${ }^{1)}$ Recent reports have indicated that hypertension and coronary heart disease are frequently seen in this condition $^{2,31}$; arteriosclerosis can be considered to be a major risk factor in the development of this disease. In the present case, the patient is young, only 25 years old and with normolipidemia. Aortography (Fig. 2) showed no irregularity in the aortic walls. Therefore, it is unlikely that arteriosclerosis is the cause of the abdominal aneurysm.

Some cases known as inflammatory aneurysms, comprising between 5 to $10 \%$ of all aneurysms, are associated with a thickened, often calcified aortic wall and periaortic inflammatory tissues which are contrast-enhanced by CT scan. ${ }^{4), 5)}$ The aortic lumen in the present case is enlarged and surrounded by thrombus but abnormal periaortic tissues were not observed on CT scan (Fig. 1). Ultrasound examinations also confirmed these findings. The erythrocyte sedimentation rate was $3 \mathrm{~mm} /$ hour. STS, tuberculosis and mycosis were all negative, however, in view of the presence of a leucocytosis (over $13,000 / \mathrm{mm}^{3}$ ) and a continuously positive CRP, one cannot rule out an infectious process completely. Aortitis syndrome was ruled out by aortography 
and physical examination.

Less commonly seen are congenital aortic aneurysms which sometimes accompany anomalies such as Ehler-Danlos syndrome, Marfan's syndrome or tuberous sclerosis. ${ }^{6}$ Those are easily ruled out from the patient's clinical data, and the aneurysms seen in such diseases are usually multiple and saccular, while a fusiform aneurysm extended from the tenth thoracic level to the aortic bifurcation in our patient.

The aorta was tortuous at the level of Th-10, which suggests pseudocoarctation." However, the kinking of the aorta was so small that it may not have caused aneurysmal aortic changes in the distal portion.

The absence of a history of trauma or abdominal surgery supports the possibility of idiopathic origin, a very rare subgroup of abdominal aneurysms.

The size of the kidneys was assessed by ultrasound techniques, a renoscintigram using ${ }^{99 \mathrm{~m} T \mathrm{c}-D M S A}$ (Fig. 4), CT scan and IVP, which indicated a small kidney on the right side. Aortography showed a decreased nephrogram (Fig. 2) and the renogram showed a decreased secretory segment (renal blood flow) of the right kidney (Fig. 3). The renin ratio and renin index ${ }^{8}$ data obtained indicated that renin secretion was greater from the right kidncy. The captopril test, a more specific and simpler examination for renovascular hypertension, ${ }^{9}$ ' resulted in an approximately 7 fold increase in PRA after captopril administration, which strongly suggests renovascular hypertension as reported by Muller et al.9) Significant reductions in blood pressure after administration of captopril and an angiotensin II analog antagonist indicate that the patient's hypertension was renin dependent. Renal artery stenosis was not proven by aortography, but the thrombus was observed mainly in the right side of the aortic lumen by CT scan (Fig. 1). It is possible that the hypertension seen in the present case was caused by an intraluminal thrombus and/or hemodynamic changes due to the aortic aneurysm which may have resulted in renal ischemia.

\section{Referenaes}

1. Castleden WM, Mercer JC: Abdominal aortic aneurysms in Western Australia: descriptive epidemiology and patterns of rupture. Br J Surg 72:109, 1985

2. Spittell JA: Hypertension and arterial aneurysm. J Am Coll Cardiol 1: 533, 1983

3. Brown OW, Hollier LH, Pairolero $\mathrm{PC}$, Kazmier FJ, McCready RA: Abdominal aortic aneurysm and coronary artery disease. Arch Surg 116: 1484, 1981

4. Cullenward MJ, Scanlan KA, Pozniak MA, Acher CA: Inflammatory aortic aneurysm (periaortic fibrosis): radiologic imaging. Radiology 159: 75, 1986

5. Feiner $\mathrm{HD}$, Raghavendra $\mathrm{BN}$, Phelps $\mathrm{R}$, Rooney L: Inflammatory abdominal aortic aneurysm: report of six cases. Hum Pathol 15: 454, 1984

6. Darden WA, Fulenwider JT, Smith RB, Sewell CW: Congenital abdominal aortic aneu- 
rysms: report of a case and review of the literature. Surgery 96: 567, 1984

7. Kawarabayashi $T$, Nishikimi $T$, Takeuchi $K$, Takeda $T$ : Pseudocoarctation of the abdominal aorta associated with renovascular hypertension. Angiology 36: 215, 1985

8. Kaplan NM: Renal vascular hypertension. in Clinical Hypertension, 4th Ed, Williams \& Wilkins, Los Angeles, p 317, 1986

9. Muller FB, Sealey JE, Case DB, Atlas SA, Pickering TG, Pecker MS, Preibisz JJ, Laragh $\mathrm{JH}$ : The captopril test for identifying renovascular disease in hypertensive patients. Am J Med 80: 633, 1986 